\title{
32. COMPARISONS BETWEEN THE OXYGEN ISOTOPIC COMPOSITION OF PORE WATER AND GLOBIGERINOIDES RUBER IN SEDIMENTS FROM HOLE 817C ${ }^{1}$
}

\author{
Peter K. Swart ${ }^{2}$
}

\begin{abstract}
The oxygen isotopic composition of pore waters squeezed from sediments in Hole 817C co-varies with the oxygen isotopic composition of Globigerinoides ruber below $8 \mathrm{mbsf}$. The magnitude of the variation in the pore water $\delta^{18} \mathrm{O}$ is approximately $30 \%$ of the variation in the foraminifers. Overall, the $\delta^{18} \mathrm{O}$ of the pore waters increases down the core, a trend that is also present in the $\mathrm{Cl}^{-}$concentrations. The variations in the $\delta^{18} \mathrm{O}$ of pore waters may be the result of either of two phenomena. First, these may reflect original variations in the waters, the magnitude of which has been subsequently reduced by process of diffusion. Second, these may reflect recrystallization of the precursor sediment and isotopic exchange between the fluids and the recrystallized sediment. At the moment data are not available to ascertain which process is responsible although the correlation between the $\mathrm{Cl}^{-}$and the $\delta^{18} \mathrm{O}$ data suggests that these values reflect the original composition modified by diffusion.
\end{abstract}

\section{INTRODUCTION}

The oxygen and hydrogen isotopic compositions of water contained in the interparticle pore space of buried sediment are initially similar to those of the bottom water at the time of deposition. With increasing age, the $\mathrm{O}$ and $\mathrm{H}$ isotopic compositions of the entrained water can be altered by (1) diagenetic interactions with the sediment, (2) mixing with waters deposited at different time periods, and/or (3) diffusion along concentration gradients. The importance of these effects has been studied by numerous researchers and was recently reviewed by Lawrence (1989). This study examines the $\delta^{18} \mathrm{O}$ composition of pore water contained in sediments from Hole $817 \mathrm{C}$ and discusses the potential importance of each of these processes for altering the oxygen isotopic composition of the pore fluids.

\section{SCIENTIFIC BACKGROUND}

Hole $817 \mathrm{C}$ is situated on the northern side of the Townsville Trough in $1016.1 \mathrm{~m}$ of water (Fig. 1). Although no sedimentological descriptions were performed for this core, it can be considered to be identical to the upper portion of Holes 817A, 817B, and 817D. Drilling in Hole $817 \mathrm{C}$ penetrated $26.9 \mathrm{~m}$ of homogeneous micritic ooze, which was squeezed at $10-\mathrm{cm}$ intervals, yielding a total of 269 samples that were processed for interstitial water analyses. The entire core is latest Pleistocene in age. The boundary between Zones CN15 and $\mathrm{CN} 14 \mathrm{~b}$ in Hole 817A was given as lying between the bottom of Cores $133-817 \mathrm{~A}-1 \mathrm{H}$ and $-2 \mathrm{H}$, and the boundary between Zones $\mathrm{CN} 14 \mathrm{~b}$ and $\mathrm{CN}-14 \mathrm{a}$ between Cores 133-817A-3H and $-4 \mathrm{H}$. Later research by Gartner (this volume) refined these age boundaries to $0.275 \mathrm{Ma}$ at $25.08 \mathrm{mbsf}$ and $0.465 \mathrm{Ma}$ at $28.07 \mathrm{mbsf}$. Further age control is presented here.

\section{METHODS}

Sediment samples were squeezed on board the JOIDES Resolution using the conventional methods (Manheim and Sayles, 1972). After filtration, samples were analyzed for alkalinity and chloride. A portion of the sample was subsequently sealed in a glass ampule for

\footnotetext{
${ }^{1}$ McKenzie, J.A., Davies, P.J., Palmer-Julson, A., et al., 1993. Proc. ODP, Sci. Results, 133: College Station, TX (Ocean Drilling Program).

${ }^{2}$ Stable Isotope Laboratory, MGG/RSMAS, University of Miami, Miami, FL 33149.
}

later $\mathrm{O}$ isotopic analyses. The oxygen isotopic composition was determined on $\mathrm{CO}_{2}$ equilibrated with $1 \mathrm{~cm}^{3}$ of sample in a water bath at $25^{\circ} \mathrm{C}$ for 24 to $36 \mathrm{hr}$ (after the method of Epstein and Mayeda, 1954). Experiments using this technique showed that equilibrium was attained in samples of normal salinity in less than $24 \mathrm{hr}$. As a result of uncertainty regarding the precise correction factors to apply for the presence of dissolved salts (Gonfiantini, 1986), I have not corrected our data for these effects. Reproducibility of oxygen isotopic analyses, determined by replicate analyses of 16 standards within a single batch of equilibrations, is $\pm 0.1 \%$.

Chlorinities were measured in the waters at the time of collection by titration with $\mathrm{AgNO}_{3}$ and standardized using IAPSO (International Association of Physical Sciences Organization) seawater. The reproducibility of this method is approximately $1 \%$.

A portion of the sediment cake was disaggregated and sieved into three size fractions. The foraminifer Globigerinoides ruber was selected from the $<120$ and $>63 \mu \mathrm{m}$ size fractions. Between 5 to 10 individuals were analyzed for their stable oxygen and carbon isotopic composition using an automated dissolution method at $90^{\circ} \mathrm{C}$ (Swart et al., 1991). The external reproducibility of this method determined by replicate analysis of standards is $\pm 0.02 \%$ for both $\mathrm{C}$ and $\mathrm{O}$.

The isotopic ratios of $\mathrm{CO}_{2}$ for both the equilibrations and dissolutions were determined using a Finnigan-MAT 251 in the Stable Isotope Laboratory (SIL) at the Rosenstiel School of Marine and Atmospheric Sciences, University of Miami. All data have been corrected for the usual interferences and are quoted relative to PDB for carbonate and SMOW for waters.

\section{RESULTS}

\section{Chloride}

The chloride concentration of the pore water varied between 540 and $560 \mathrm{mM}$ (Fig. 2). Although a gradual increase in $\mathrm{Cl}^{-}$can be seen down the core, the variations generally were within the analytical error of $\pm 1 \%$ (Table 1 ) of the measurement method employed.

\section{Alkalinity}

The alkalinity data presented in the initial reports showed an initial rapid rise in alkalinity with depth from seawater values of 2.2 to approximately $3.3 \mathrm{mM}$. This value remained fairly constant to a depth of a 8 mbsf, below which it increased rapidly to a value of $7 \mathrm{mM}$ at the bottom of the core (Fig. 3). 


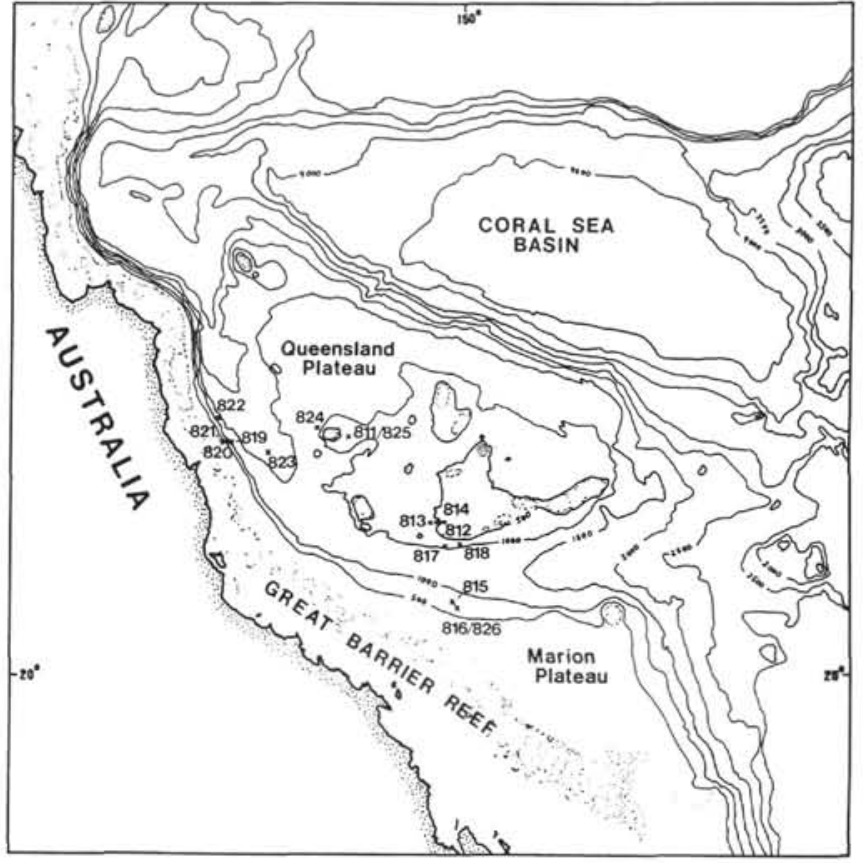

Figure 1. Location map of Site 817.

\section{Oxygen Isotopic Composition of Pore Water}

The oxygen isotopic composition of the pore water varied between approximately -0.6 and $+0.7 \%$ SMOW (Fig. 4 ). These variations were greater than the analytical error in our measurement technique $( \pm 0.1 \%$; see above) and showed systematic changes down the core. The average oxygen isotopic composition of the pore waters increases toward the base of the core.

\section{Carbon and Oxygen Isotopic Composition of Foraminifers}

The $\delta^{18} \mathrm{O}$ of $G$. ruber varied between -2.0 and $+0.6 \%$ (PDB) and showed variation, which might be interpreted as glacial-interglacial stages. The $\delta^{13} \mathrm{C}$ was variable and was not correlated with the $\delta^{18} \mathrm{O}$ (Fig. 5).

\section{Revised Age Assignments}

Based on the oxygen isotope stratigraphy shown in Figure 5, ages have been assigned to the various isotopic stages (Fig. 6). In this curve, I have identified most of the stages established by Imbrie et al. (1984). This chronology also agrees well with the FAD of Emiliania huxleyi at 25.07 mbsf (Gartner, this volume). The sedimentation rate profile calculated from these ages is shown in Figure 7.

\section{Correlation Between $G$. ruber and Oxygen Isotopic Composition of Pore Fluids}

The oxygen isotopic composition of the pore waters shows systematic variations, which below 8 mbsf, are correlatable with variations in the oxygen isotopic composition of $G$. ruber. Although this correlation is statistically significant, the significance increases substantially if the data are plotted as five sample moving averages (Fig. 8). In the lower portion of the core, the range in the $\delta^{18} \mathrm{O}$ of the pore water varies between approximately 0.0 to $0.5 \%$ compared to an almost $1.5 \%$ variation in the isotopic composition of the foraminifers. In the upper $8 \mathrm{mbsf}$, there appears to be no correlation between the $\delta^{18} \mathrm{O}$ of the pore fluids and foraminifers, and the magnitude of the

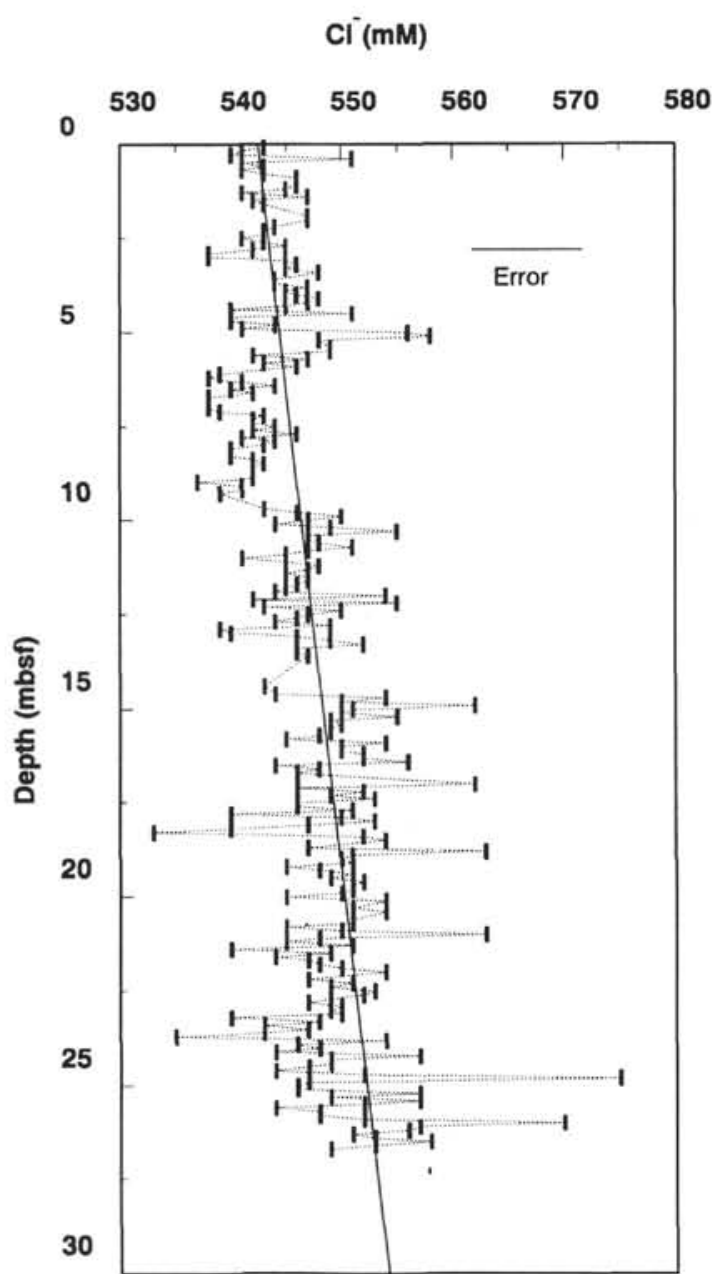

Figure 2. Chloride concentration of pore waters from Hole 817C; error bar indicates $\times 1 \%$. Regression line represents trend in $\mathrm{Cl}^{-}$concentration with depth.

variations in the oxygen isotopic composition of the pore fluids is greater $(-0.5-0.5 \%)$. Overall, a tendency for the pore waters to increase is seen in $\delta^{18} \mathrm{O}$ values below 13 mbsf. This trend is similar to one seen in the $\mathrm{Cl}^{-}$data.

\section{DISCUSSION}

The changes in the $\mathrm{O}$ isotopic composition of the pore fluids result from either a diagenetic signal (i.e., recrystallization of the carbonate sediment) or variations in the bottomwater signature at the time of deposition that have been subsequently modified by diffusion. A definitive method to test whether the oxygen isotopic compositions of the pore fluids are driven by carbonate recrystallization will be to measure the hydrogen isotopic composition of the pore waters, as this value is unaffected by diagenesis (Lawrence, 1989). If the $\delta \mathrm{D}$ of the pore water co-varies with that of the $\delta^{18} \mathrm{O}$, then the signal represents a modified original bottomwater signature. If no co-variation exists between the isotopic composition of these two elements, then in all probability the variations in the $\delta^{18} \mathrm{O}$ result from carbonate recrystallization. Certain aspects of the present data can support either of these two hypotheses. The original pore-water idea is supported by the weak correlation between $\mathrm{Cl}^{-}$and $\delta^{18} \mathrm{O}$ down the core. The absence of a stronger correlation is a result of scatter in the $\mathrm{Cl}^{-}$data caused by the relatively high analytical errors involved in the technique relative to the measured change.

Support for carbonate recrystallization is evident in data collected for the $\mathrm{Sr}^{2+}$ concentration from Hole $817 \mathrm{~A}$ and the alkalinity from 


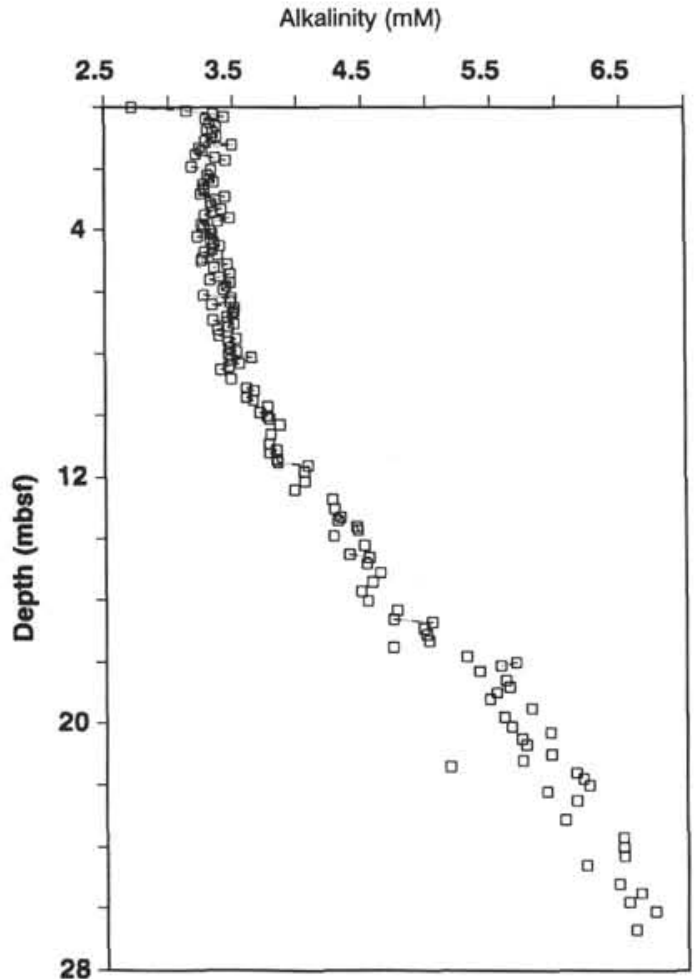

Figure 3. Alkalinity of pore waters from Hole $817 \mathrm{C}$.

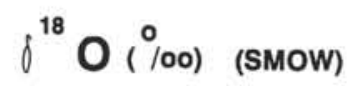

$\begin{array}{llllllll}-0.8 & -0.6 & -0.4 & -0.2 & 0.2 & 0.4 & 0.6 & 0.8\end{array}$

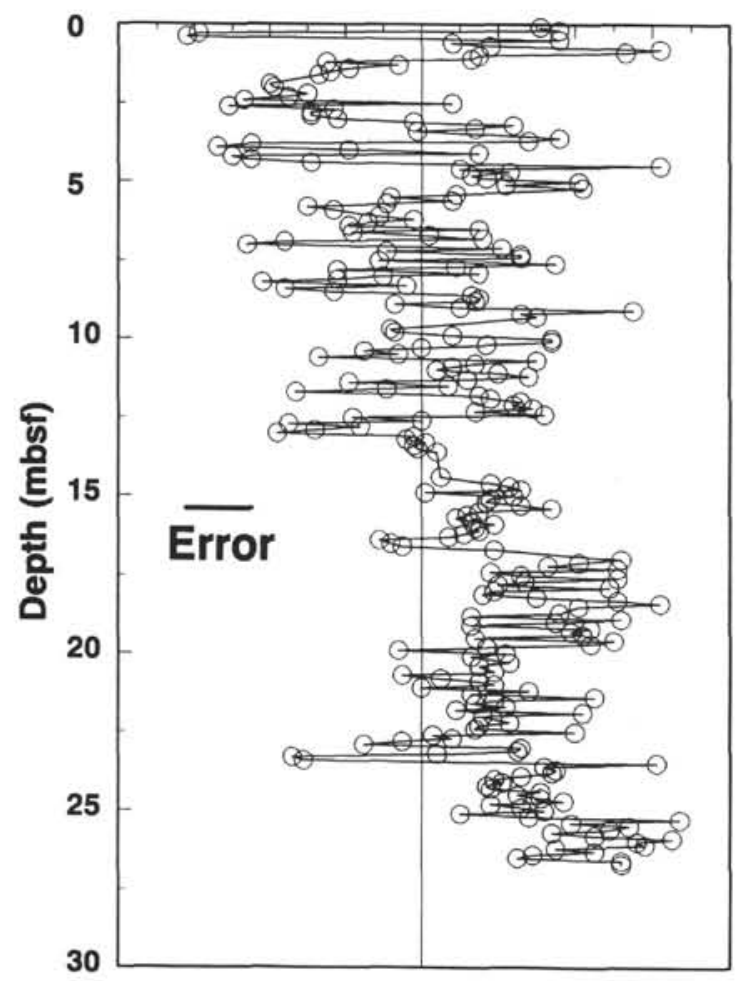

Figure 4. Oxygen isotopic composition of pore waters from Hole $817 \mathrm{C}$. Error bar represents $\times 0.1 \%$.

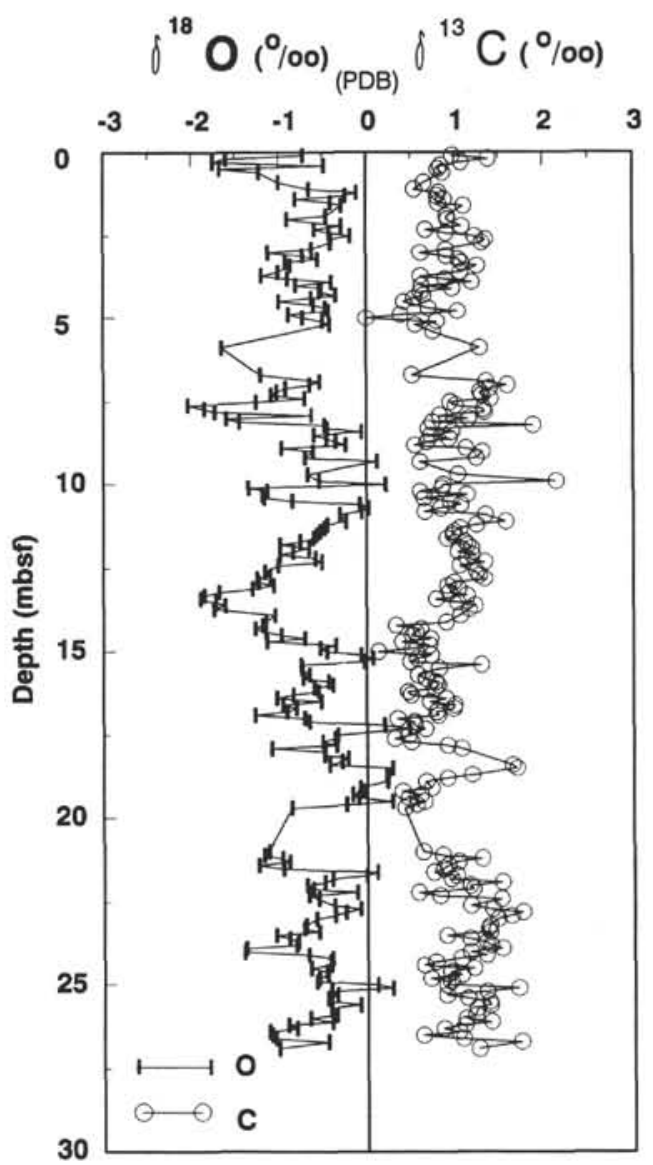

Figure 5. Carbon and oxygen isotopic compositions of Globigerinoides ruber from Hole $817 \mathrm{C}$.

Hole 817C (Davies, McKenzie, Palmer-Julson, et al., 1990), which show evidence of extensive recrystallization throughout. The fact that the alkalinity gradient is much stronger below 8 mbsf at Hole $817 \mathrm{C}$ suggests that much more extensive carbonate recrystallization has occurred in this portion of the hole. This is coincidently the region of the hole in which the $\delta^{18} \mathrm{O}$ of the pore fluids and the $\delta^{18} \mathrm{O}$ of the foraminifers co-vary.

The absence of co-variation in the upper portion of the hole also poses an interesting problem. Either this discrepancy is also a consequence of diagenetic alteration, or it reflects waters of differing isotopic composition at the surface and at the bottom at this time period. The latter idea can be tested by examining the isotopic composition of a benthic species (such as Cibicides wuellerstorfi) over this time interval. A difference in isotopic composition between the bottom and surface waters also might imply that the stratigraphy established for the upper portion of the hole may not be correct because the surface waters are being influenced by fluids of unusual isotopic composition.

The notion of rapid depletion in the pore water $\delta^{18} \mathrm{O}$ in the upper portion of the hole being a result of diagenesis is supported by models of carbonate recrystallization such as presented by Killingley (1983). In this model, the isotopic composition of the pore water after a specified amount of recrystallization can be calculated from the following equation:

$$
\delta w_{\alpha}=\frac{M_{c} R\left(\delta C_{i}+10^{3}\left(1-\alpha_{T}\right)+M_{w} \delta w_{i}\right)}{M_{w}+M_{c} \alpha_{T} R}
$$

In this equation, $\delta w_{C a}=\delta^{18} \mathrm{O}$ of interstitial water after recrystallization, $\delta C_{i}=\delta^{18} \mathrm{O}$ of calcium carbonate of initial sediment, $\delta w_{\alpha}=$ 
Table 1. Geochemical data from Hole $817 \mathrm{C}$ including stable $\mathrm{O}$ and $\mathrm{C}$ isotope data from G. ruber, porewater $\delta^{18} \mathrm{O}$ and $\mathrm{Cl}$ measurements.

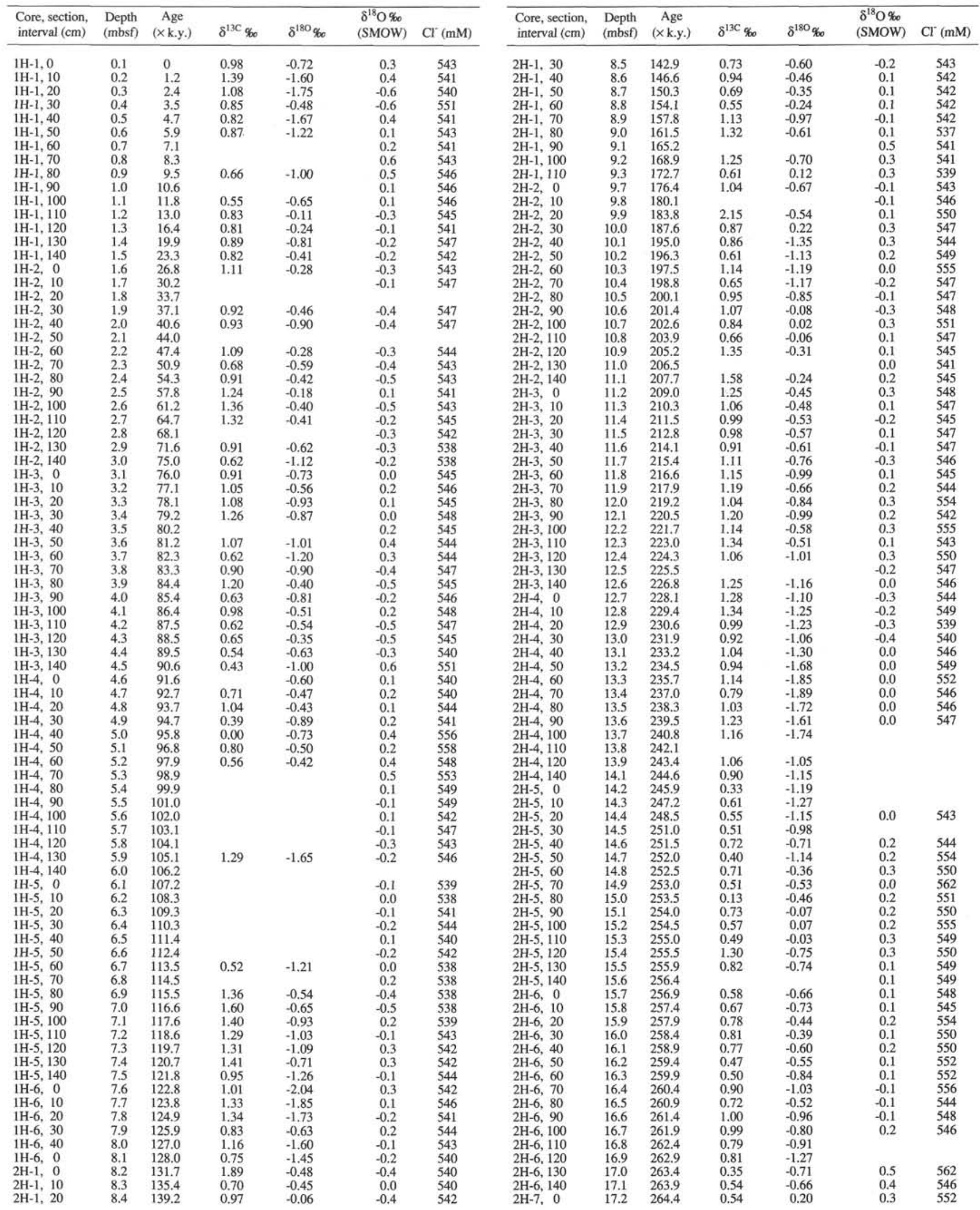


Table 1 (continued).

\begin{tabular}{|c|c|c|c|c|c|c|c|c|c|c|c|c|c|}
\hline $\begin{array}{l}\text { Core, section, } \\
\text { interval }(\mathrm{cm})\end{array}$ & $\begin{array}{l}\text { Depth } \\
\text { (mbsf) }\end{array}$ & $\begin{array}{c}\text { Age } \\
(\times \text { k.y. })\end{array}$ & $\delta^{13 C} q_{60}$ & $\delta^{180} \%_{0}$ & $\begin{array}{l}\delta^{18} \mathrm{O} \%_{\infty} \\
\text { (SMOW) }\end{array}$ & $\mathrm{Cl}^{-}(\mathrm{mM})$ & $\begin{array}{l}\text { Core, section, } \\
\text { interval }(\mathrm{cm})\end{array}$ & $\begin{array}{l}\text { Depth } \\
\text { (mbsf) }\end{array}$ & $\begin{array}{c}\text { Age } \\
(\times k . y .)\end{array}$ & $\delta^{13 C} q_{0}$ & $\delta^{180} \%_{\infty}$ & $\begin{array}{l}\delta^{18} \mathrm{O} \% \\
(\mathrm{SMOW})\end{array}$ & $\mathrm{Cl}^{-}(\mathrm{mM})$ \\
\hline $2 \mathrm{H}-7,10$ & 17.3 & 264.8 & 0.66 & 0.48 & 0.5 & 549 & $3 \mathrm{H}-3,120$ & 22.2 & 289.1 & 0.58 & -0.12 & 0.2 & 547 \\
\hline $2 \mathrm{H}-7,20$ & 17.4 & 265.3 & & & 0.2 & 553 & $3 \mathrm{H}-3,130$ & 22.3 & 289.6 & 0.82 & -0.67 & 0.1 & 551 \\
\hline $2 \mathrm{H}-7,30$ & 17.5 & 265.8 & 0.47 & -0.34 & 0.3 & 546 & $3 \mathrm{H}-3,140$ & 22.4 & 290.1 & 1.52 & -0.56 & 0.1 & 549 \\
\hline $2 \mathrm{H}-7,40$ & 17.6 & 266.3 & 0.31 & -0.37 & 0.5 & 546 & $3 \mathrm{H}-3,0$ & 22.5 & 290.6 & & & 0.4 & 553 \\
\hline $2 \mathrm{H}-7,50$ & 17.7 & 266.8 & 0.50 & -0.51 & 0.3 & 551 & $3 \mathrm{H}-4,10$ & 22.6 & 291.1 & 1.17 & -0.38 & 0.0 & 552 \\
\hline $2 \mathrm{H}-7,60$ & 17.8 & 267.3 & 0.91 & -0.35 & 0.2 & 540 & $3 \mathrm{H}-4,20$ & 22.7 & 291.6 & 1.42 & -0.08 & 0.1 & 549 \\
\hline $2 \mathrm{H}-7,70$ & 17.9 & 267.8 & 1.07 & -1.09 & 0.5 & 550 & $3 \mathrm{H}-4,30$ & 22.8 & 292.1 & 1.76 & -0.25 & 0.0 & 547 \\
\hline $3 \mathrm{H}-1,0$ & 18.0 & 268.3 & & -0.48 & 0.2 & 553 & $3 \mathrm{H}-4,40$ & 22.9 & 292.5 & 1.63 & -0.37 & -0.2 & 550 \\
\hline $3 \mathrm{H}-1,10$ & 18.1 & 268.8 & & -0.49 & 0.2 & 547 & $3 \mathrm{H}-4,50$ & 23.0 & 293.0 & 1.48 & -0.58 & 0.3 & 549 \\
\hline $3 \mathrm{H}-1,20$ & 18.2 & 269.3 & & -0.22 & 0.3 & 540 & $3 \mathrm{H}-4,60$ & 23.1 & 293.5 & & & 0.2 & 550 \\
\hline $3 \mathrm{H}-1,30$ & 18.3 & 269.8 & & -0.29 & 0.5 & 533 & $3 \mathrm{H}-4,70$ & 23.2 & 294.0 & 1.39 & -0.70 & 0.0 & 540 \\
\hline $3 \mathrm{H}-1,40$ & 18.4 & 270.3 & 1.65 & -0.43 & 0.6 & 552 & $3 \mathrm{H}-4,80$ & 23.3 & 294.5 & 1.37 & -0.72 & -0.3 & 548 \\
\hline $3 \mathrm{H}-1,0$ & 18.5 & 270.8 & 1.70 & 0.29 & 0.4 & 554 & $3 \mathrm{H}-4,90$ & 23.4 & 295.0 & 1.39 & -0.55 & -0.3 & 543 \\
\hline $3 \mathrm{H}-1,60$ & 18.6 & 271.3 & & & 0.3 & 550 & $3 \mathrm{H}-4,100$ & 23.5 & 295.5 & 0.90 & -1.04 & 0.6 & 547 \\
\hline $3 \mathrm{H}-1,70$ & 18.7 & 271.8 & 1.19 & 0.22 & 0.4 & 547 & $3 \mathrm{H}-4,110$ & 23.6 & 296.0 & 1.16 & -0.89 & 0.3 & 543 \\
\hline $3 \mathrm{H}-1,80$ & 18.8 & 272.3 & 0.91 & 0.24 & 0.1 & 563 & $3 \mathrm{H}-4,120$ & 23.7 & 296.5 & 1.35 & -0.79 & 0.3 & 535 \\
\hline $3 \mathrm{H}-1,90$ & 18.9 & 272.8 & 0.67 & 0.23 & 0.5 & 551 & $3 \mathrm{H}-4,130$ & 23.8 & 297.0 & 1.40 & -0.81 & 0.3 & 554 \\
\hline $3 \mathrm{H}-1,100$ & 19.0 & 273.3 & & & 0.4 & 550 & $3 \mathrm{H}-4,140$ & 23.9 & 297.5 & 1.53 & -1.38 & 0.3 & 546 \\
\hline $3 \mathrm{H}-1,110$ & 19.1 & 273.8 & 0.73 & -0.08 & 0.1 & 551 & $3 \mathrm{H}-5,0$ & 24.0 & 298.0 & 1.17 & -1.40 & 0.2 & 548 \\
\hline $3 \mathrm{H}-1,120$ & 19.2 & 274.2 & 0.40 & -0.05 & 0.4 & 545 & $3 \mathrm{H}-5,10$ & 24.1 & 298.5 & 1.35 & -0.67 & 0.2 & 544 \\
\hline $3 \mathrm{H}-1,130$ & 19.3 & 274.7 & 0.61 & -0.17 & 0.4 & 548 & $3 \mathrm{H}-5,20$ & 24.2 & 299.0 & 1.06 & -0.40 & 0.2 & 557 \\
\hline $3 \mathrm{H}-1,140$ & 19.4 & 275.2 & 0.47 & -0.10 & 0.4 & 551 & $3 \mathrm{H}-5,30$ & 24.3 & 299.5 & 0.77 & -0.43 & 0.2 & 549 \\
\hline $3 \mathrm{H}-2, \quad 0$ & 19.5 & 275.7 & 0.65 & 0.29 & 0.1 & 549 & $3 \mathrm{H}-5,40$ & 24.4 & 300.0 & 0.64 & -0.42 & 0.3 & 549 \\
\hline $3 \mathrm{H}-2,10$ & 19.6 & 276.2 & 0.56 & -0.24 & 0.5 & 552 & $3 \mathrm{H}-5,50$ & 24.5 & 300.5 & 1.20 & -0.65 & 0.3 & 547 \\
\hline $3 \mathrm{H}-2,20$ & 19.7 & 276.7 & 0.43 & -0.86 & 0.4 & 551 & $3 \mathrm{H}-5,60$ & 24.6 & 3010 & 0.94 & -0.47 & 0.3 & 544 \\
\hline $3 \mathrm{H}-2,30$ & 19.8 & 277.2 & & & 0.2 & 551 & $3 \mathrm{H}-5,70$ & 24.7 & 301.5 & 1.06 & -0.46 & 0.4 & 552 \\
\hline $3 \mathrm{H}-2,40$ & 19.9 & 277.7 & & & -0.1 & 550 & $3 \mathrm{H}-5,80$ & 24.8 & 301.9 & 0.71 & -0.56 & 0.2 & 575 \\
\hline $3 \mathrm{H}-2,50$ & 20.0 & 278.2 & & & 0.2 & 545 & $3 \mathrm{H}-5,90$ & 24.9 & 302.4 & 0.94 & -0.58 & 0.3 & 547 \\
\hline $3 \mathrm{H}-2,60$ & 20.1 & 278.7 & & & 0.1 & 554 & $3 \mathrm{H}-5,100$ & 25.0 & 302.9 & 0.89 & 0.11 & 0.3 & 546 \\
\hline $3 \mathrm{H}-2,70$ & 20.2 & 279.2 & & & & & $3 \mathrm{H}-5,110$ & 25.1 & 303.4 & 1.71 & 0.28 & 0.1 & 546 \\
\hline $3 \mathrm{H}-2,80$ & 20.3 & 279.7 & & & 0.2 & 551 & $3 \mathrm{H}-5,120$ & 25.2 & 303.9 & 1.35 & -0.42 & 0.3 & 557 \\
\hline $3 \mathrm{H}-2,90$ & 20.4 & 280.2 & & & 0.2 & 554 & $3 \mathrm{H}-5,130$ & 25.3 & 304.4 & 0.89 & -0.35 & 0.7 & 549 \\
\hline $3 \mathrm{H}-2,100$ & 20.5 & 280.7 & & & & & $3 \mathrm{H}-5,140$ & 25.4 & 304.9 & 1.13 & -0.46 & 0.4 & 557 \\
\hline $3 \mathrm{H}-2,110$ & 20.6 & 281.2 & & & 0.2 & 551 & $3 \mathrm{H}-6,0$ & 25.5 & 305.4 & 1.38 & -0.43 & 0.5 & 552 \\
\hline $3 \mathrm{H}-2,120$ & 20.7 & 281.7 & & & -0.1 & 551 & $3 \mathrm{H}-6,10$ & 25.6 & 305.9 & 1.39 & -0.09 & 0.5 & 544 \\
\hline $3 \mathrm{H}-2,130$ & 20.8 & 282.2 & & & 0.0 & 545 & $3 \mathrm{H}-6,20$ & 25.7 & 306.4 & 1.24 & -0.42 & 0.3 & 548 \\
\hline $3 \mathrm{H}-2,140$ & 20.9 & 282.7 & & & 0.1 & 550 & $3 \mathrm{H}-6,30$ & 25.8 & 306.9 & & & 0.5 & 548 \\
\hline $3 \mathrm{H}-3, \quad 0$ & 21.0 & 283.2 & 0.63 & -1.12 & 0.2 & 563 & $3 \mathrm{H}-6,40$ & 25.9 & 307.4 & 1.22 & -0.36 & 0.7 & 552 \\
\hline $3 \mathrm{H}-3,10$ & 21.1 & 283.6 & 0.85 & -1.18 & 0.0 & 548 & $3 \mathrm{H}-6,50$ & 26.0 & 307.9 & 1.11 & -0.66 & 0.6 & 570 \\
\hline $3 \mathrm{H}-3,20$ & 21.2 & 284.1 & 1.30 & -0.97 & 0.3 & 545 & $3 \mathrm{H}-6,60$ & 26.1 & 308.4 & 1.40 & -0.41 & 0.6 & 557 \\
\hline $3 \mathrm{H}-3,30$ & 21.3 & 284.6 & 1.03 & -0.89 & 0.1 & 551 & $3 \mathrm{H}-6,70$ & 26.2 & 308.9 & 1.10 & -0.91 & 0.3 & 556 \\
\hline $3 \mathrm{H}-3,40$ & 21.4 & 285.1 & 0.91 & -1.24 & 0.4 & 540 & $3 \mathrm{H}-6,80$ & 26.3 & 309.4 & 0.86 & -0.81 & 0.4 & 551 \\
\hline $3 \mathrm{H}-3,50$ & 21.5 & 285.6 & 0.86 & -0.96 & 0.2 & 549 & $3 \mathrm{H}-6,90$ & 26.4 & 309.9 & 1.03 & -1.12 & 0.3 & 553 \\
\hline $3 \mathrm{H}-3,60$ & 21.6 & 286.1 & 0.75 & 0.11 & 0.1 & 544 & $3 \mathrm{H}-6,100$ & 26.5 & 310.4 & 0.63 & -1.09 & 0.3 & 558 \\
\hline $3 \mathrm{H}-3,70$ & 21.7 & 286.6 & 1.01 & -0.01 & 0.2 & 547 & $3 \mathrm{H}-6,110$ & 26.6 & 310.8 & 1.08 & -1.05 & 0.5 & 553 \\
\hline $3 \mathrm{H}-3,80$ & 21.8 & 287.1 & 0.95 & -0.40 & 0.1 & 548 & $3 \mathrm{H}-6,120$ & 26.7 & 311.3 & 1.74 & -0.45 & 0.5 & 549 \\
\hline $3 \mathrm{H}-3,90$ & 21.9 & 287.6 & 1.53 & -0.49 & 0.4 & 550 & $3 \mathrm{H}-6,130$ & 26.8 & 311.8 & & & & \\
\hline $3 \mathrm{H}-3,100$ & 22.0 & 288.1 & 1.16 & -0.69 & 0.2 & 554 & $3 \mathrm{H}-6,140$ & 26.9 & 312.3 & 1.26 & -1.01 & & 549 \\
\hline
\end{tabular}

$\delta^{18} \mathrm{O}$ of interstitial waters before reaction, $M_{\mathrm{c}}=$ mole fraction of oxygen in carbonate sediment, $M_{\mathrm{w}}=$ mole fraction of oxygen in pore waters, $R=$ percentage of recrystallization, and $\alpha=$ fractionation factor between calcite-water.

In the case for Hole $817 \mathrm{C}$, I have used a bottom temperature of $10^{\circ} \mathrm{C}$, a geothermal gradient of $50^{\circ} \mathrm{C} / \mathrm{km}$ (data from Davies, McKenzie, Palmer-Julson, et al., 1990), an initial sediment isotopic composition of $-2 \%$ (PDB), a water isotopic composition of $0.5 \%$ (SMOW) (Fig. 9), a porosity of $50 \%$, and a carbonate content of $80 \%$. If in this case one assumes that the recrystallized calcium carbonate does not re-equilibrate with the pore fluids, then the isotopic composition of the pore waters will rapidly become depleted with depth. This is similar to the case at Hole $817 \mathrm{C}$. As may be observed from this simplistic example the result of initial recrystallization is to produce pore waters that are isotopically depleted. If the pore waters do not continue to react with the carbonate, then the isotopic composition of the fluid should in the absence of diffusion remain at approximately $-1.0 \%$. However, continued recrystallization of the sediment may cause the isotopic composition of the fluids to co-vary with the foraminifers, as is observed in the lower portion of Hole $817 \mathrm{C}$.

The origin of these $\delta^{18} \mathrm{O}$ values will be further tested by (1) constructing a mathematical model that will account for not only diffusion, but also advection, and carbonate recrystallization, (2) measurement of the $\delta \mathrm{D}$ of the pore waters, and (3) measurement of the isotopic composition of benthic foraminifers from the cores.

\section{CONCLUSIONS}

There is a co-variance between the oxygen isotopic composition of $G$. ruber and the pore waters below 8 mbsf. The magnitude of the variation in the $\delta^{18} \mathrm{O}$ of the waters is approximately $30 \%$ of that seen in the $\delta^{18} \mathrm{O}$ of the foraminifers, suggesting that diffusion and perhaps recrystallization have altered the isotopic compositions. Circumstantial evidence exists to support both of these hypotheses, and the eventual cause will only be revealed by (1) analyzing the hydrogen isotopic composition of the pore fluids, (2) mathematically modeling the processes of carbonate recrystallization, diffusion, and advection, and (3) investigating the isotopic composition of the benthic foraminifers.

\section{ACKNOWLEDGMENTS}

The author would like to thank the technicians, scientists, and crew of Leg 133 for continued help throughout the cruise. Joe Powers, Joe DeMorett, and Scott Chaffey are especially thanked for their help in 
the chemistry laboratory. Alex Isern, Danny Muller, and Judy McKenzie provided friendship and discussion throughout. I would especially like to thank all those who helped with the marathon squeezing effort. In addition to those mentioned above, Christian Betzler, George Dix, David Feary, Craig Glenn, Jose Martin, Lucien Montaggioni, and Chris Pigram manned the presses during the 36-hr squeezing effort. Help with the shore-based analyses was provided by Amel Saied, Jeff Abell, and Jim Leder. Thanks to Michael Lopez and Yvette Alger for many hours of selecting foraminifers. Conversations with Geoff Haddad, Andre Droxler, Larry Peterson, and Pam Reid helped with the interpretation of the oxygen isotope stratigraphy.

\section{REFERENCES}

Davies, P.J, McKenzie, J.A., Palmer-Julson, A., et al., 1991. Proc. ODP., Init. Repts., 133: College Station, TX (Ocean Drilling Program).

Epstein, S., and Mayeda, T., 1953. Variation of ${ }^{18} \mathrm{O}$ content of waters from natural sources. Geochim. Cosmochim. Acta, 42:213-224.

Gonfiantini, R., 1986. Environmental isotopes in lake studies. In Fritz, P., and Fontes, J.Ch. (Eds.) Handbook of Environmental Isotope Geochemistry, Vol 2., (Elsevier), 113-168.

Imbrie, J., Hays, J.D., Martinson, D.G., McIntyre, A., Mix, A., Morley, J.J, Pisias, N.G, Prell, W.L, and Schackleton, N.J, 1984. The orbital theory of

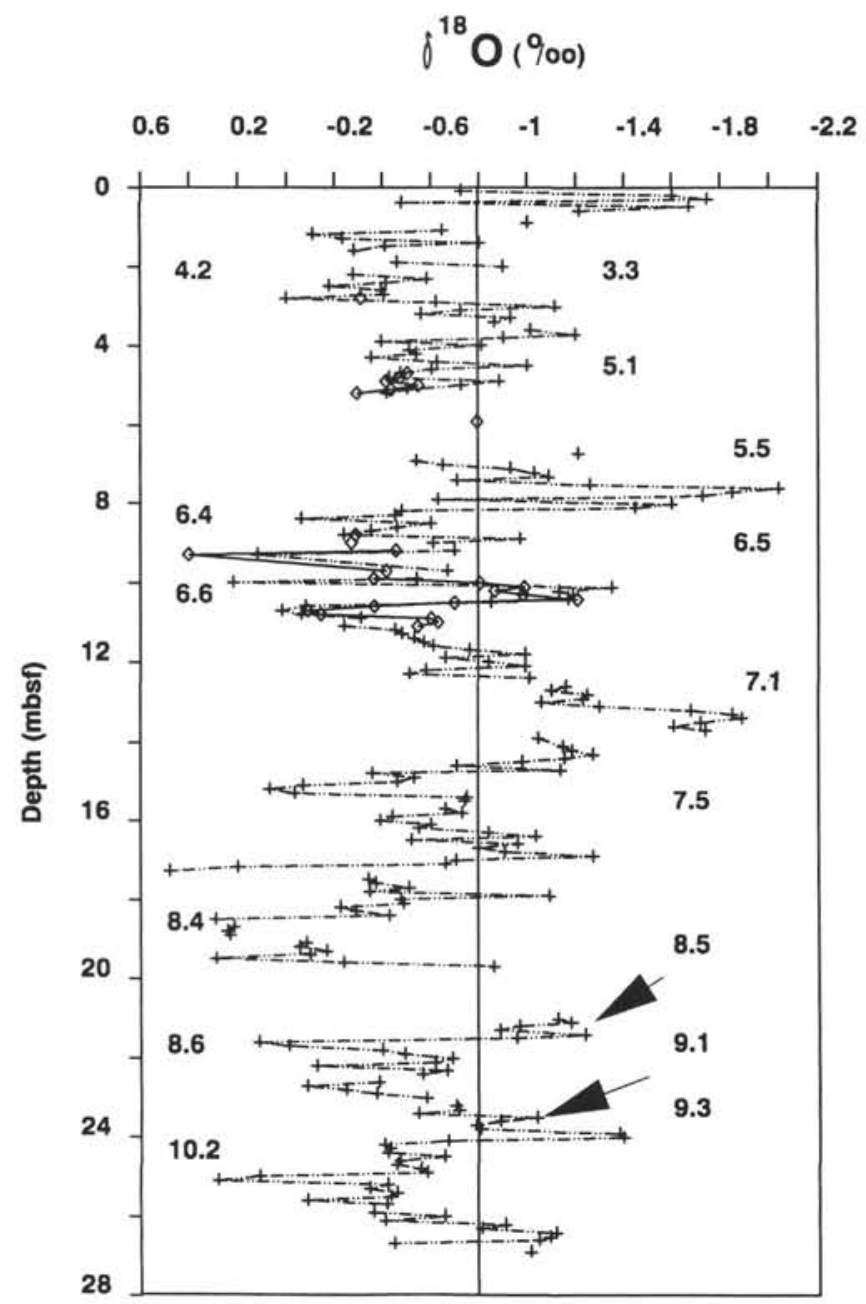

Figure 6. Oxygen isotopic stratigraphy of Hole $817 \mathrm{C}$. The diamonds and the solid lines represent replicated data. Stage numbers are from Imbrie et al. (1984).
Pleistocene climate: support from a revised chronology of the marine $\delta^{18} \mathrm{O}$ record. In Berger, A.L., et al. (Eds.), Milankovitch and Climate, Pt. I: New York (Reidel Publ. Co.), 269-305.

Killingley, J.S., 1983. Effects of diagenetic recrystallization on ${ }^{18} \mathrm{O} /{ }^{16} \mathrm{O}$ values of deep-sea sediments. Nature, 301:594-597.

Lawrence, J.R., 1989. The stable isotope geochemistry of deep-sea pore water. In Fritz, P., and Fontes, J.Ch. (Eds.), Handbook of Environmental Isotope Geochemistry, Vol. 3: New York (Elsevier), 317-356.

Manheim, F.T., and Sayles, F.L., 1974. Composition and origin of interstitial waters of marine sediments based on deep sea drill cores. In Goldberg, E.D., The Sea, Vol. 5: New York (Wiley), 527-568.

Swart, P.K., Burns, S.J., and Leder, J.J., 1991. Fractionation of the stable isotopes of $\mathrm{O}$ and $\mathrm{C}$ in $\mathrm{CO}_{2}$ during the reaction of calcite with phosphoric acid as a function of temperature and technique. Chem. Geol. (Isotope Geosci. Sect.), 86:89-96.

Abbreviations for names of organizations and publication titles in ODP reference lists follow the style given in Chemical Abstracts Service Source Index (published by American Chemical Society).

Date of initial receipt: 21 April 1992

Date of acceptance: 10 December 1992

Ms 133SR-260

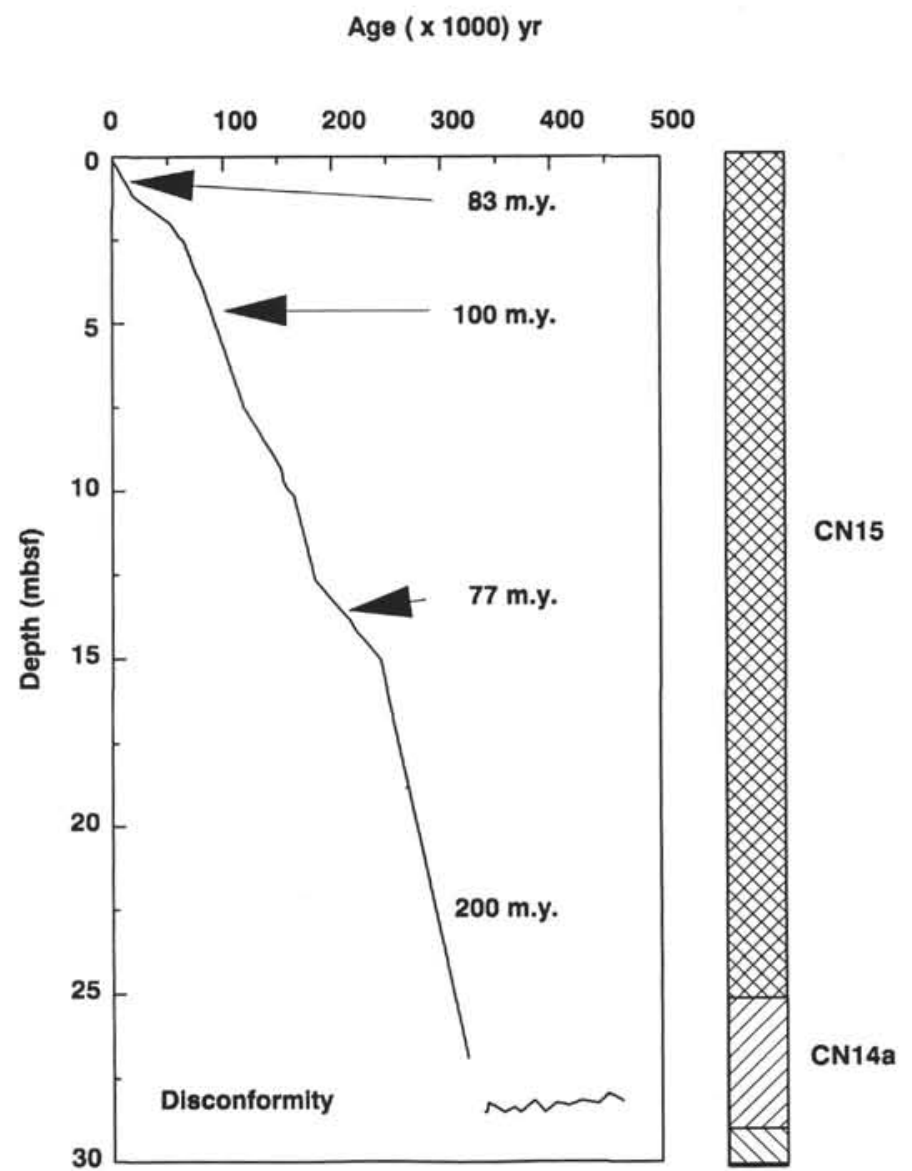

Figure 7. Sedimentation rate for Hole 817C. Nannofossil zones are from Gartner (this volume). 


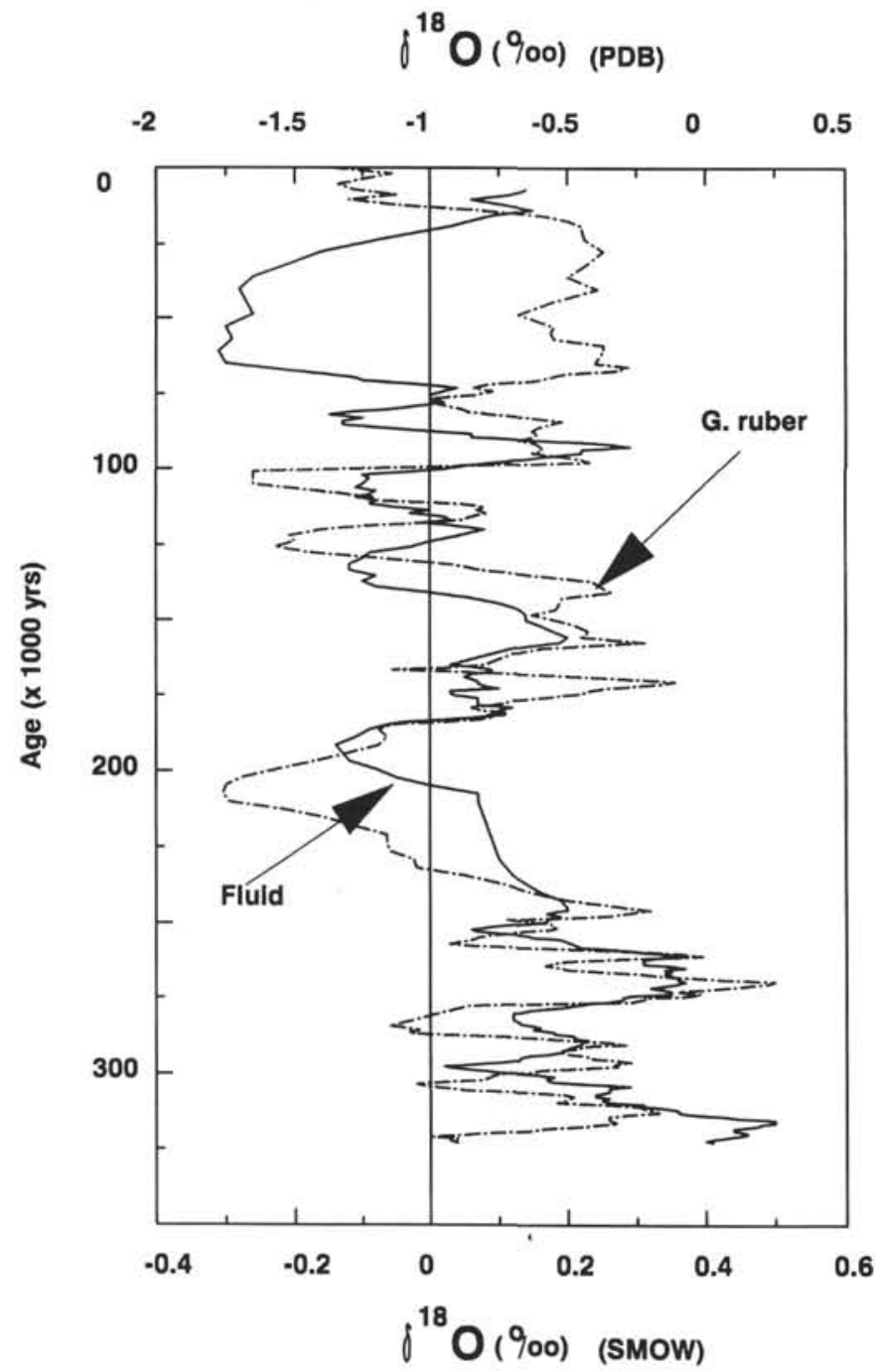

Figure 8. Smoothed oxygen isotopic composition of the pore waters compared to $G$. ruber from Hole $817 \mathrm{C}$.

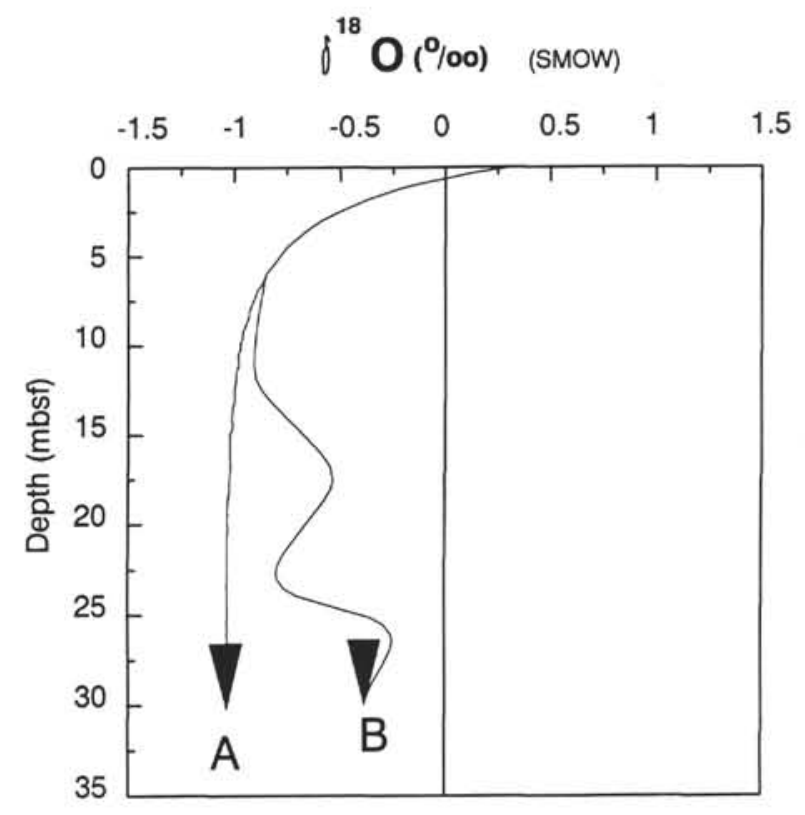

Figure 9. Theoretical effect of carbonate recrystallization on the $\delta^{18} \mathrm{O}$ of pore waters using the following parameters $\left(\delta^{18} \mathrm{O}_{i}=-2 \%(\mathrm{PDB}) ; \delta^{18} \mathrm{Ow}=+0.5 \%\right.$ $(\mathrm{SMOW}) ; d t / d z=50^{\circ} \mathrm{C} / \mathrm{km}$; and bottom temperature $=10^{\circ} \mathrm{C}$ ). Line $(\mathrm{A})$ represents pore water which initially experiences a great deal of recrystallization and little subsequent isotopic exchange with the sediments. Line (B) shows pore water which continues to isotopically exchange with the sediments. 